\title{
Another two new species of the millipede family Glomeridae from Vietnam, with a new record of Rhopalomeris variegata Golovatch et Semenyuk, 2016 from southern Vietnam (Diplopoda: Glomerida)
}

\author{
Ещё два новых вида многоножек семейства Glomeridae из \\ Вьетнама, с новой находкой Rhopalomeris variegata Golovatch et \\ Semenyuk, 2016 из Южного Въетнама (Diplopoda: Glomerida)
}

\author{
S. I. Golovatch \\ С.И. Головач
}

Institute for Problems of Ecology and Evolution, Russian Academy of Sciences, Moscow, Russia; E-mail: sgolovatch@yandex.ru Институт проблем экологии и эволюции РАН, Ленинский проспект 33, Москва 119071, Россия.

KEY WORDS: Hyperglomeris, Hyleoglomeris, new species, key, Rhopalomeris variegata, variation, Vietnam. КЛЮЧЕВЫЕ СЛОВА: Hyperglomeris, Hyleoglomeris, новый вид, ключ, Rhopalomeris variegata, изменчивость, Вьетнам.

ABSTRACT. Hyperglomeris nigra sp.n. is described from the Phu Tho Province, northern Vietnam, differing from the remaining five congeners primarily by the entirely blackish dorsum and in several details of telopod structure. All six currently known species of Hyperglomeris are keyed. Hyleoglomeris fedorenkoi sp.n. is described from the Dak Lak Province, southern Vietnam, likewise differing from congeners in its characteristic colour pattern and by certain details of telopod structure. In addition, Rhopalomeris variegata Golovatch et Semenyuk, 2016 is newly recorded from the Kon Tum Province, southern Vietnam, with notes on variation.

РЕЗЮМЕ. Из Северного Вьетнама, провинция Пу-То, описан новый вид Hyperglomeris nigra sp.n., отличающийся от остальных пяти видов рода, прежде всего, совершенно черноватым верхом и некоторыми деталями строения телопода. Дан ключ для всех шести известных видов Hyperglomeris. Из провинции Дак-Лак (Южный Вьетнам) описан новый вид Hyleoglomeris fedorenkoi sp.n., тоже отличающийся от других видов рода характерной окраской и определенными деталями строения телопода. Кроме того, Rhopalomeris variegata Golovatch et Semenyuk, 2016 впервые отмечен в провинции Кон-Тум (Южный Вьетнам), с данными об его изменчивости.

\section{Introduction}

The millipede family Glomeridae in the fauna of Vietnam is the richest in entire Indochina, presently comprising 18 species in five genera [Golovatch et al., 2013; Golovatch, Semenyuk, 2016]. Three of the genera, including Hyperglomeris Silvestri, 1917, as well as all species are endemic to Vietnam.
This paper puts on record another new Hyperglomeris from northern Vietnam and another new Hyleoglomeris Verhoeff, 1910 from southern Vietnam. A new record of the recently described Rhopalomeris variegata Golovatch et Semenyuk, 2016 from outside the Gia Lai Province, the terra typica, is also provided, this time in the adjacent Kon Tum Province, southern Vietnam.

\section{Material and methods}

All material, including the holotypes of the new species, was recently received for study from the collectors, D.N. Fedorenko and I.I. Semenyuk (both Moscow, Russia). At present the material is deposited in the collection of the Zoological Museum, State University of Moscow, Russia (ZMUM).

Both photography and focus stacking were performed by K.V. Makarov (Moscow, Russia).

\section{Taxonomic part}

$$
\text { Hyperglomeris nigra Golovatch, sp.n. }
$$

Figs 1-9.

HOLOTYPE $\sigma^{7}$ (ZMUM), Vietnam, Phu Tho Prov., ca $90 \mathrm{~km}$ NW of Hanoi, Xuan Son National Park, N 21 $07^{\prime} 52^{\prime \prime}$, E $104^{\circ} 57^{\prime} 07^{\prime \prime}$, 400-470 m a.s.1., 6-15.VI.2014, leg. D. Fedorenko.

NAME. To emphasize the entirely blackish dorsum.

DIAGNOSIS. Differs from other species of the genus primarily by the entirely blackish dorsum and in several details of telopod structure. See also Key below.

DESCRIPTION. Length ca $24 \mathrm{~mm}$, width (maximum on tergum 2) ca $13 \mathrm{~mm}$. Dorsum entirely blackish with contrasting grey-olive or -yellowish, narrow, lateral and caudal margins of all terga, including collum and anal shield; ocelli also blackish; extremely faint traces of an axial line and 
large, transverse-oval, marbled, sublateral spots on terga sometimes discernible as well. Antennae mostly brown to dark brown, only antennomere 8 light. Head largely dark brown, with only a few marbled brown markings; labrum lighter, yellowish. Venter light brown, legs yellowish (Figs $1-3)$.

Tergal tegument smooth and shining. Ocelli $8+1$, convex. Tömösváry's organ transverse-oval, ca 1.3 times wider than long, light grey-yellowish. Antennomere 6 unusually long, ca 2.5-2.6 times as long as high, dorsal margin clearly concave (Figs 3-5). Antennomere 8 with only four small, apical, sensory cones.

Collum with two transverse striae.

Tergum 2 (= thoracic shield) with a small and narrow hyposchism not reaching behind caudal tergal margin; seven superficial, but regular, complete, transverse striae laterally and dorsolaterally: three starting below schism, one level with, all others (at least three) above schism, with 3-4 crossing the dorsum; mid-dorsal region with a number (3-4) of additional, incomplete, broken, confused, mostly short striolae behind last regular stria (Figs 1-2).

Anal shield slightly, but clearly emarginate medially at caudal margin (Figs 3-4).
Legs 17 (Fig. 6) strongly reduced, with a high, regularly rounded, outer coxal lobe; telopodite 4-segmented, with one apical and one ventro-apical spine.

Legs 18 (Fig. 7) less strongly reduced, with an ogival syncoxital notch; telopodite also 4-segmented, tarsus with only one strong apical spine.

Legs 19, or telopods (Figs 8-9), very strongly incrassate, with a high, trapeziform. apically slightly concave, central, syncoxital lobe flanked by two densely setose horns, each latter about as high as syncoxital lobe, faintly clavate and crowned by a tiny, spiniform, acuminate filament. Prefemur distocaudally with a short trichostele (pf) crowned by a short trichoid flagellum. Femur with a large, simple, distocaudal process (fp), the latter about as long as tibia, set at ca $100^{\circ}$ to femur and bearing a small, membranous, apical sac. Tibia distocaudally with two small tubercles, one longitudinal (a), the other transverse (b). Tarsus rather strongly curved, subacuminate apically.

REMARKS. The genus Hyperglomeris Silvestri, 1917 has hitherto been known to comprise five species, all in northern Vietnam [Silvestri, 1917; Golovatch, 1983; Golovatch et al., 2013]: H. lamellosa Silvestri, 1917, the typespecies, and H. dirupta (Silvestri, 1917), both from the Lang
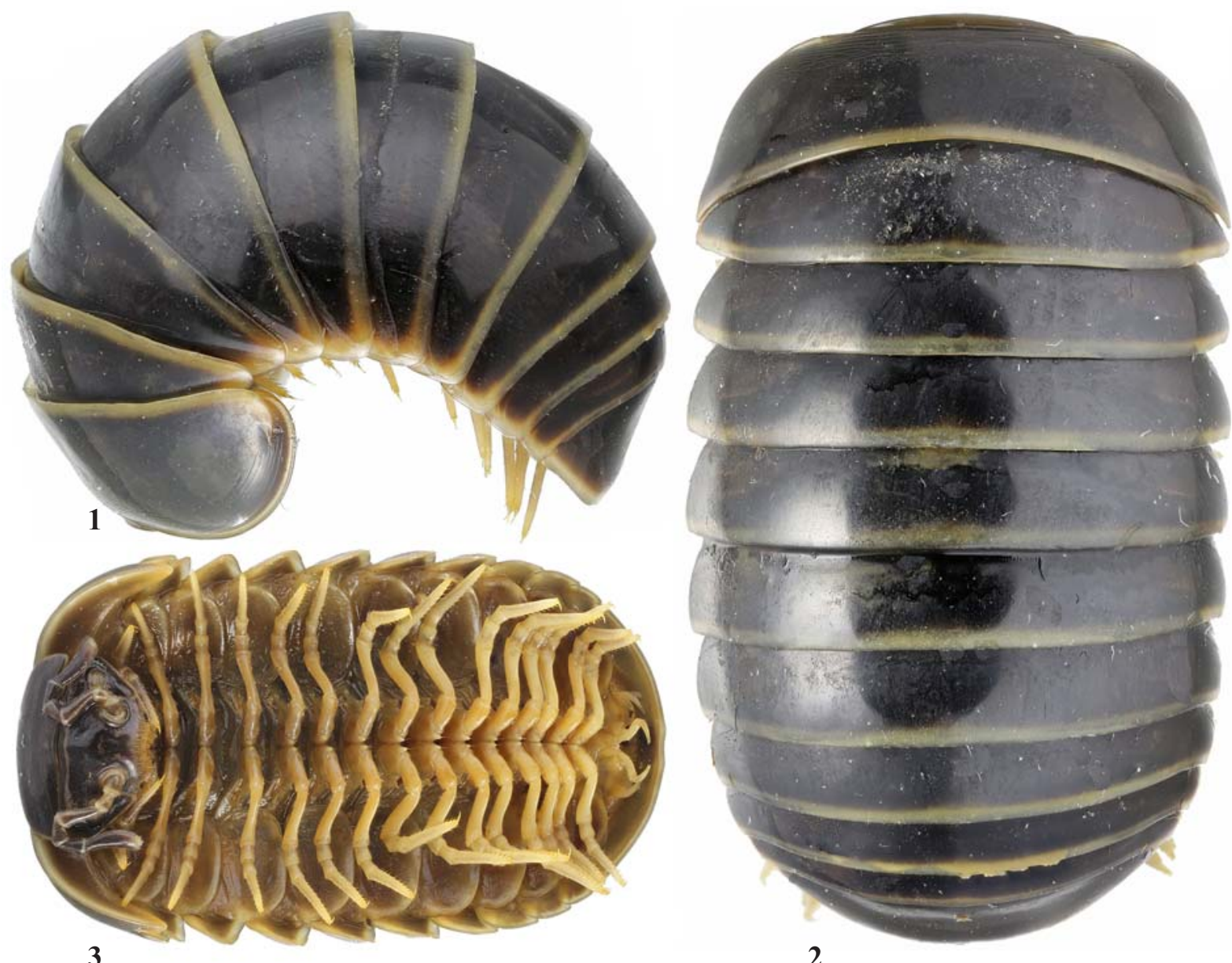

Figs 1-3. Hyperglomeris nigra sp.n., $0^{\top}$ holotype, habitus, lateral, dorsal and ventral views, respectively. Pictures by K. Makarov, taken not to scale.

Рис. 1-3. Hyperglomeris nigra sp.n., голотип О`, общий вид, соответственно сбоку, сверху и снизу. Фотографии К. Макарова, снято без масштаба. 


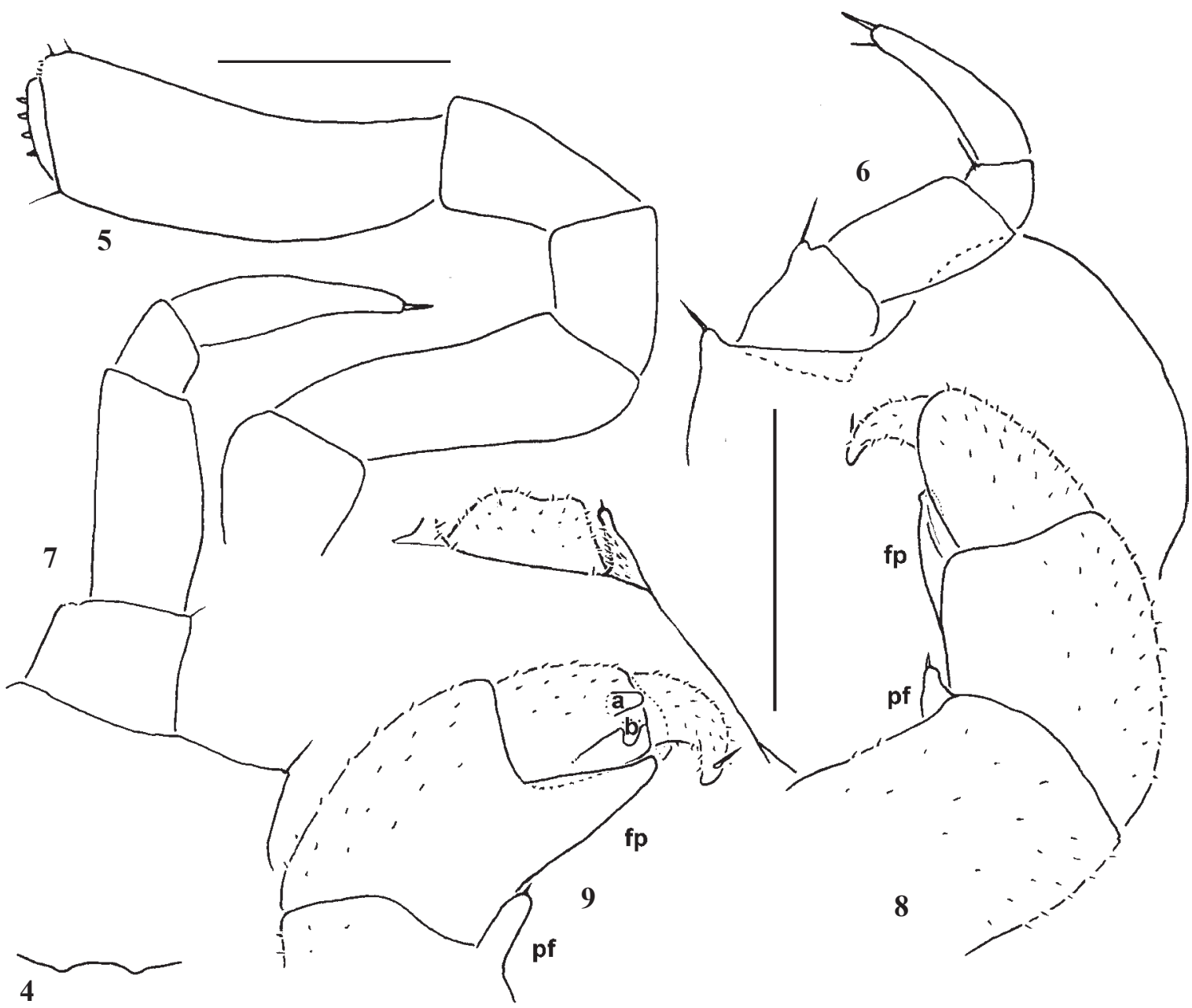

Figs 4-9. Hyperglomeris nigra sp.n., ${ }^{7}$ holotype: 4 - caudomedian region of anal shield, dorsal view; 5 - antenna, lateral view; 6 leg 17, oral view; 7 - leg 18, oral view; 8 - telopod, oral view; 9 - distal part of telopod, caudal view. Scale bars - 1.0 mm. Designations in text.

Рис. 4-9. Hyperglomeris nigra sp.n., голотип ऽ’: 4 - задне-медиальный район анального щитка, сверху; 5 - антенна, сбоку; 6 - нога 17, спереди; 7 - нога 18, спереди; 8 - телопод, спереди; 9 - дистальная часть телопода, сзади. Масштаб - 1,0 мм. Обозначения в тексте.

Son Province, H. maxima Golovatch, 1983 and H. conspicua Golovatch, 1983, both from the Hoa Binh Province, and $H$. depigmentata Golovatch, Geoffroy et Mauriès, 2013, a presumed troglobiont from a cave in the Thanh Hoa Province.

The following key can be proposed to incorporate the new species.

1(2) Body completely unpigmented, pallid

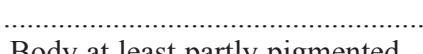
H. depigmentata

2(1) Body at least partly pigmented

3(4) Dorsum entirely blackish (except for narrow light lateral and caudal margins of terga) H. nigra sp.n.

4(3) Dorsum with evident light markings

5(6) Anal shield entirely, tergum 2 partly or entirely unpigmented; tergum 2 without fine straiae, but with a conspicuous sulcus anterodorsad of schism

H. conspicua

6(5) Both anal shield and tergum 2 at least partly with dark pigment.

7(8) Dorsum with a thin, dark, axial line against a light background....

H. maxima
8(7) Dorsum without a dark axial line, background coloration either black or red-yellow

9(10) Telopod syncoxital lobe trapeziform and truncate, its ventral margin straight H. dirupta

10(9) Telopod syncoxital lobe semi-circular, its ventral margin rounded H. lamellosa

\section{Hyleoglomeris fedorenkoi Golovatch, sp.n.} Figs 10-18.

HOLOTYPE $0^{\top}$ (ZMUM), Vietnam, Dak Lak Prov., Chu Yang Sin National Park, N 12 $23^{\prime} 48^{\prime \prime}$, E $108^{\circ} 20^{\prime} 59^{\prime \prime}$, upper flow of Krong Kmar River, 1000 m a.s.1., 30.III.-14.IV.2012, leg. D. Fedorenko. NAME. Honours D.N. Fedorenko, the collector.

DIAGNOSIS. Differs from other species of the genus primarily by the characteristic colour pattern and in several details of telopod structure, in particular the shape of the syncoxite.

DESCRIPTION. Length ca $21 \mathrm{~mm}$, width (maximum on tergum 2) ca $10 \mathrm{~mm}$. Dorsum mainly blackish brown with contrasting grey to yellowish, narrow, lateral and caudal margins of all terga, including collum and anal shield; ocelli 
also blackish; extremely faint traces of an axial line and large, evident, transverse-oval, marbled, sublateral spots on terga $2-11$. Head, collum and much of antennae light yellowish to yellow-brown, only antennomeres 5-7 infuscate, brownish. Tergite 2 broadly light yellowish along lateral and anterolateral margins. Anal shield with a large, vague, subtriangular, light spot wide and especially light at base and merging with a similarly light, yellow band at caudal margin. Venter light, mostly yellowish (Figs 10-12).

Tergal tegument smooth and shining. Ocelli $8+1$, convex, contrasting blackish against a light yellowish background of head. Tömösváry's organ transverse-oval, ca 1.2-1.3 times wider than long, as light as background of head. Antennomere 6 ca 2.2-2.3 times as long as high, dorsal margin only slightly concave (Figs 12-13). Antennomere 8 with only four small, apical, sensory cones.

Collum with two transverse striae.

Tergum 2 with a small and narrow hyposchism reaching behind up to caudal tergal margin (Fig. 10); eleven superficial, but regular, complete, transverse striae laterally and dorsolaterally: three starting below schism, two level with, all others above schism; uppermost stria particularly short and not crossing the dorsum; altogether six striae crossing it; middorsal region with an additional, incomplete, broken, confused, short striola behind last regular stria (Fig. 10). Terga 3-11 each with two arcuate lateral striae.

Anal shield regularly rounded at caudal margin (Figs 3-4).
Legs 17 (Fig. 14) strongly reduced, with a high, regularly rounded, outer coxal lobe; telopodite 4-segmented, with one apical spine.

Legs 18 (Fig. 15) less strongly reduced, with an ogival syncoxital notch; telopodite also 4-segmented, tarsus also with one strong apical spine.

Telopods (Figs 16-18), very strongly incrassate, with a high, subquadrate, central, syncoxital lobe flanked by two densely setose horns, each latter nearly as high as syncoxital lobe, directed unusually ventromesad and acuminate at tip. Prefemur distomesally with a prominent trichostele crowned by a long trichoid flagellum. Femur with a similar, but smaller trichostele distomesally and a large, simple, squarish, distocaudal process. Tibia distocaudally with a small, but evident, round tubercle at base of a small apicomesal process, the latter with a membranous sac on top, but devoid of a seta at base. Tarsus clearly curved, subacuminate apically.

REMARKS. Hyleoglomeris Verhoeff, 1910 is the largest and most widespread genus not only in the family Glomeridae, but also the entire order Glomerida. It dominates the Oriental fauna of Glomerida, at the moment counting 100+ species which range from Serbia and Greece in the west, through Anatolia, the Caucasus, Central Asia and the Himalayas, to China, Korea, Japan and Taiwan in the east, and from Indochina to the Philippines and Sulawesi Island, Indonesia in the southeast [Golovatch, 2015]. The bulk of species
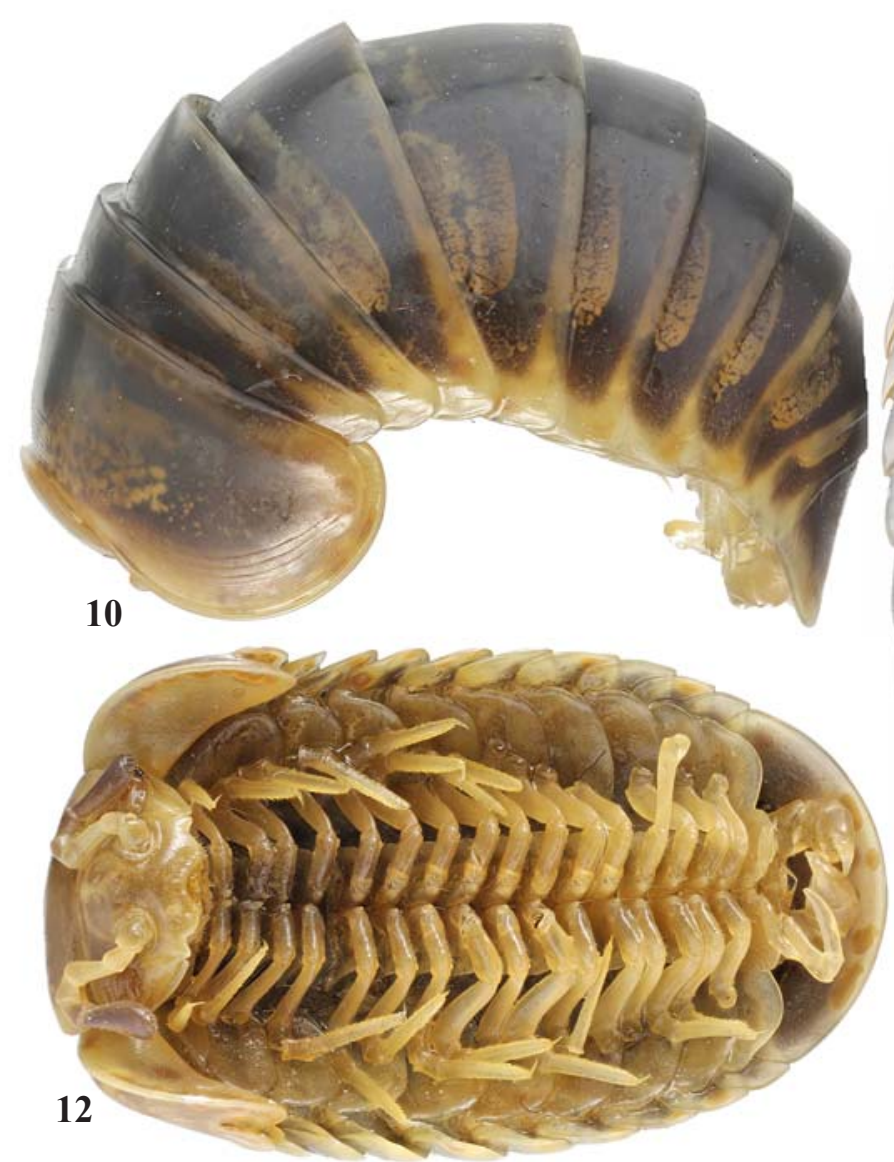

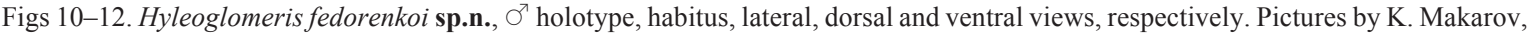
taken not to scale.

Рис. 10-12. Hyleoglomeris fedorenkoi sp.n., голотип Оフ, общий вид, соответственно сбоку, сверху и снизу. Фотографии К. Макарова, снято без масштаба. 


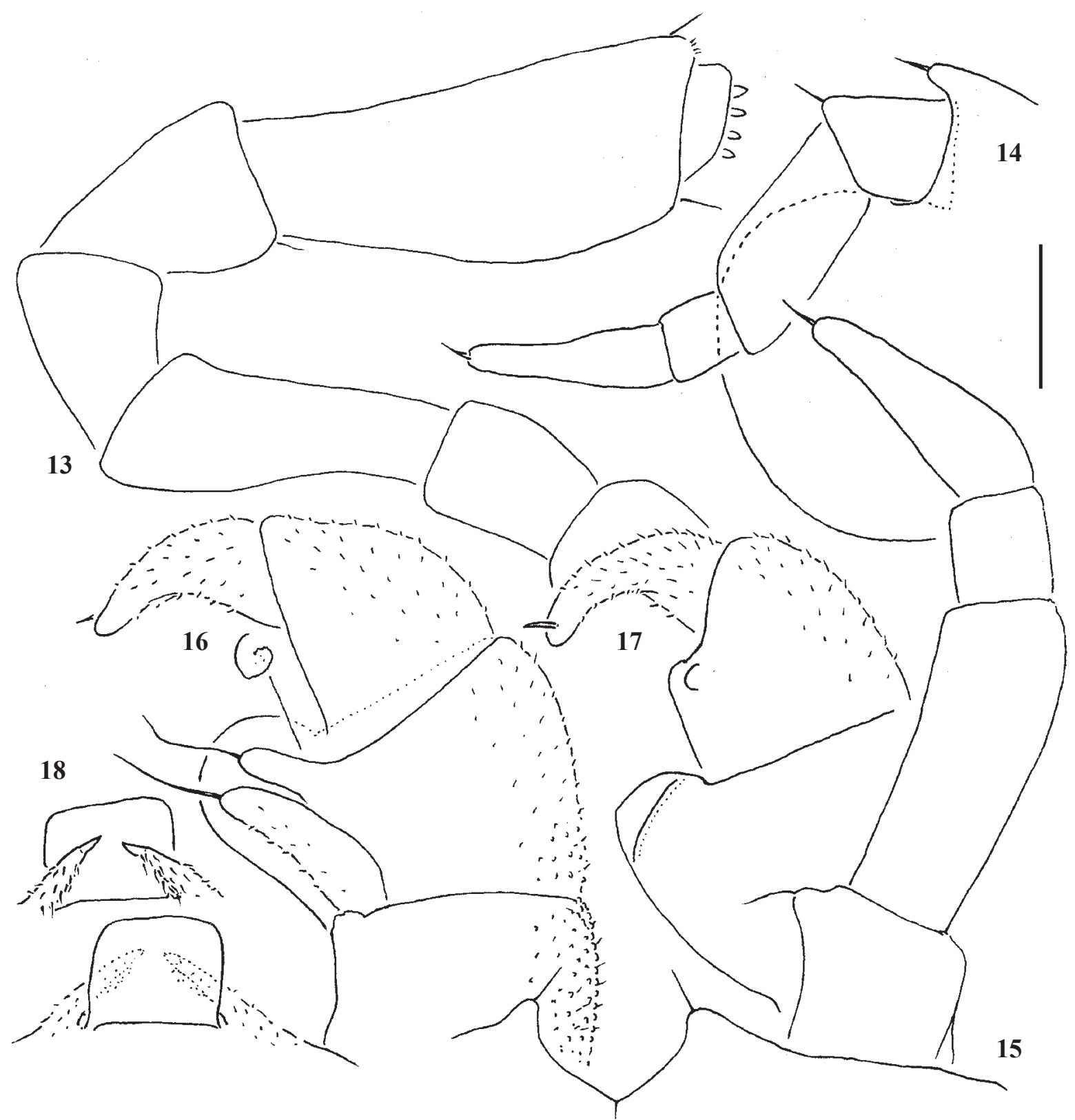

Figs 13-18. Hyleoglomeris fedorenkoi sp.n., ơ holotype: 13 - antenna, lateral view; 14 — leg 17, oral view; 15 - leg 18, oral view; 16 - telopod, oral view; 17 - distal part of telopod, caudal view; 18 - syncoxite, caudal view. Scale bar - $0.5 \mathrm{~mm}$.

Рис. 13-18. Hyleoglomeris fedorenkoi sp.n., голотип О’: 13 - антенна. сбоку; 14 - нога 17, спереди; 15 - нога 18, спереди; 16 - телопод, спереди; 17 - дистальная часть телопода, сзади; 18 - синкоксит, сзади. Масштаб - 0,5 мм.

diversity is confined to southeastern and eastern Asia [Golovatch, Semenyuk, 2016]. Vietnam supports some seven Hyleoglomeris spp. [Golovatch et al., 2006, 2013; Golovatch, Semenyuk, 2016], which is certainly an underestimate.

The conformation of the telopod syncoxite in $\mathrm{H}$. $\mathrm{fe}$ dorenkoi sp.n. is very unusual (Figs 16-18), resembling the situation observed only in H. sinensis (Brölemann, 1896), from Tibet and Sichuan, China [Golovatch et al., 2006]. However, the syncoxital horns in $H$. fedorenkoi sp.n. are directed ventromesad, not strictly mesad, and they are simple ( $v s$ denticulate), while the central lobe is high and subquadrate ( $v s$ lower and subtrapeziform).

\section{Rhopalomeris variegata Golovatch et Semenyuk,} 2016

Figs 19-33.

MATERIAL. $1 \sigma^{7}$ (ZMUM), Vietnam, Kon Tum Prov., Kon Plong Distr., N 14 $43^{\prime}$, E $108^{\circ} 19^{\prime}$, Bak Khe River, 1030 m a.s.l., 8 23.IV.2015, leg. D. Fedorenko; $1 \mathrm{O}^{\top}, 4$ 우 (ZMUM), same locality, $\mathrm{N} 14^{\circ} 43.450^{\prime} \mathrm{E} 108^{\circ} 18.882^{\prime}, 1000-1260 \mathrm{~m}$ a.s.l., tropical forest, on logs, V.2015, leg. I.I. Semenyuk.

REMARKS. This species has very recently been described from the Gia Lai Province in southern Vietnam [Golovatch, Semenyuk, 2016]. The new samples which all come from the adjacent Kon Tum Province range between 17 

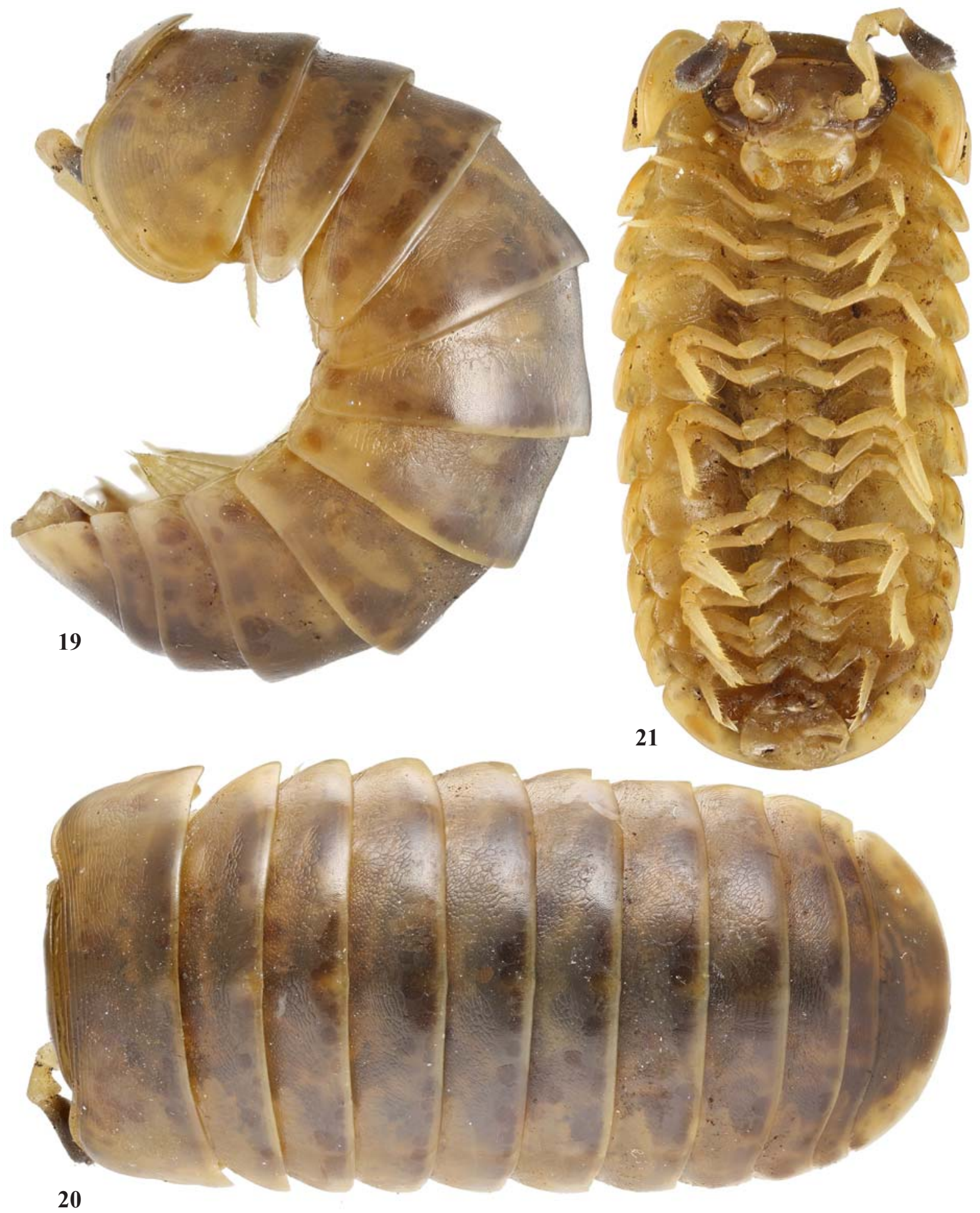

Figs 19-21. Rhopalomeris variegata Golovatch et Semenyuk, 2016, lighter $O^{7}$ from Kon Tum Province, habitus, lateral, dorsal and ventral views, respectively. Pictures by K. Makarov, taken not to scale.

Рис. 19-21. Rhopalomeris variegata Golovatch et Semenyuk, 2016, более светлый О7 из провинции Кон-Тум, общий вид, соответственно сбоку, сверху и снизу. Фотографии К. Макарова, снято без масштаба.

and $19 \mathrm{~mm}$ in length, between 7 and $8.5 \mathrm{~mm}$ in width. The original description is exact, but it can now be complemented with the following observations on variation.
General coloration of dorsum from rather light brown to nearly blackish, usually with variegated, marbled, brownyellow to yellow markings; venter much lighter (Figs 19-24). 

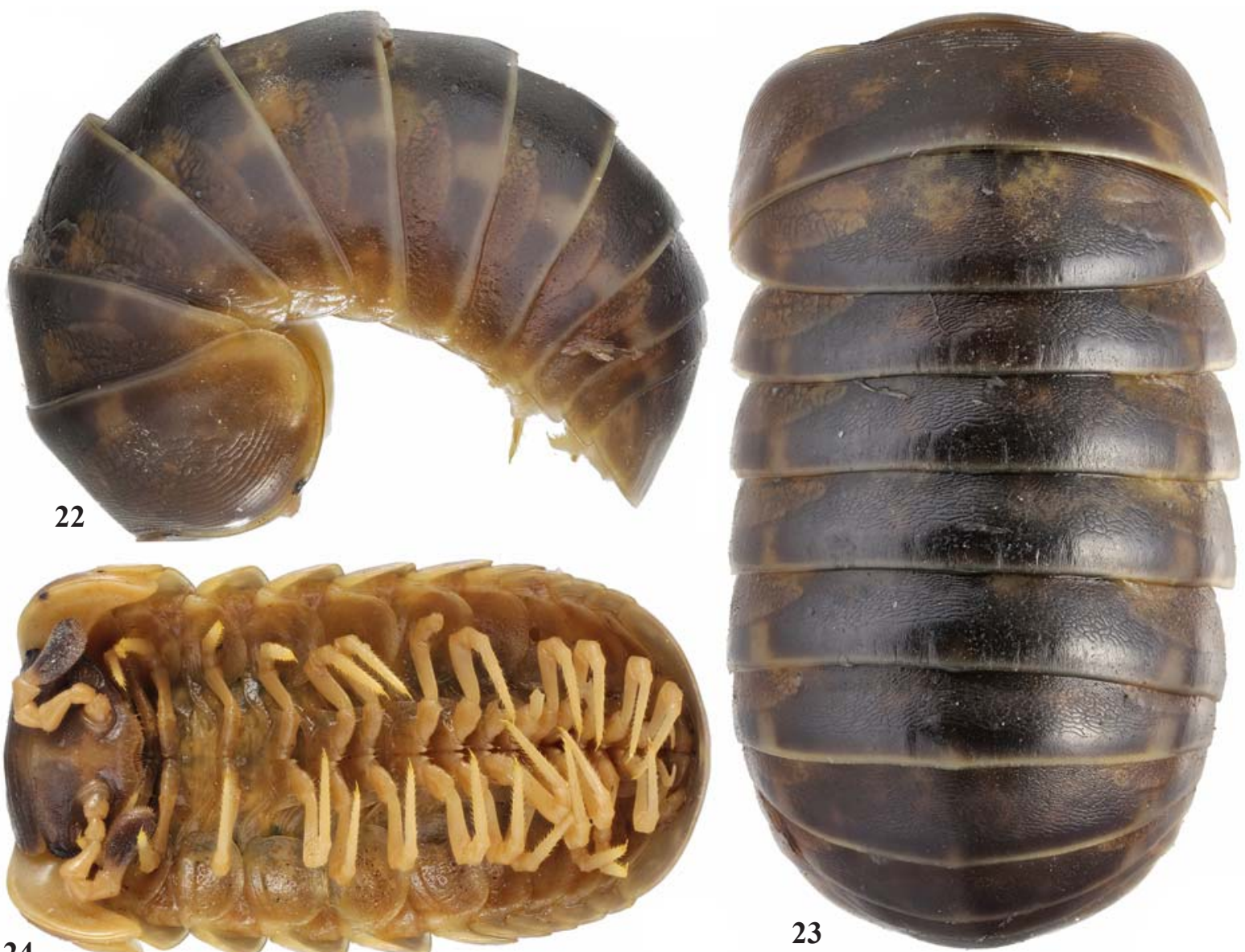

24

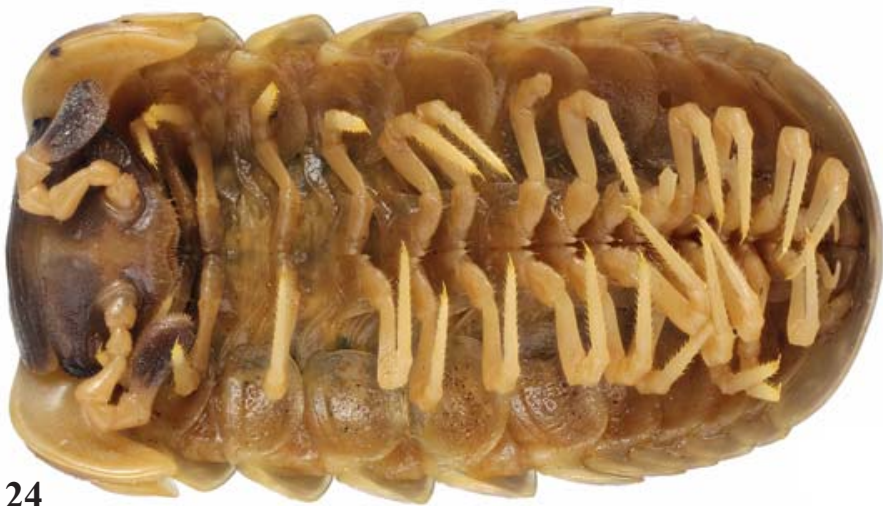

Figs 22-24. Rhopalomeris variegata Golovatch et Semenyuk, 2016, darker ${ }^{7}$ from Kon Tum Province, habitus, lateral, dorsal and ventral views, respectively. Pictures by K. Makarov, taken not to scale.

Рис. 22-24. Rhopalomeris variegata Golovatch et Semenyuk, 2016, более тёмный О’ из провинции Кон-Тум, общий вид, соответственно сбоку, сверху и снизу. Фотографии К. Макарова, снято без масштаба.

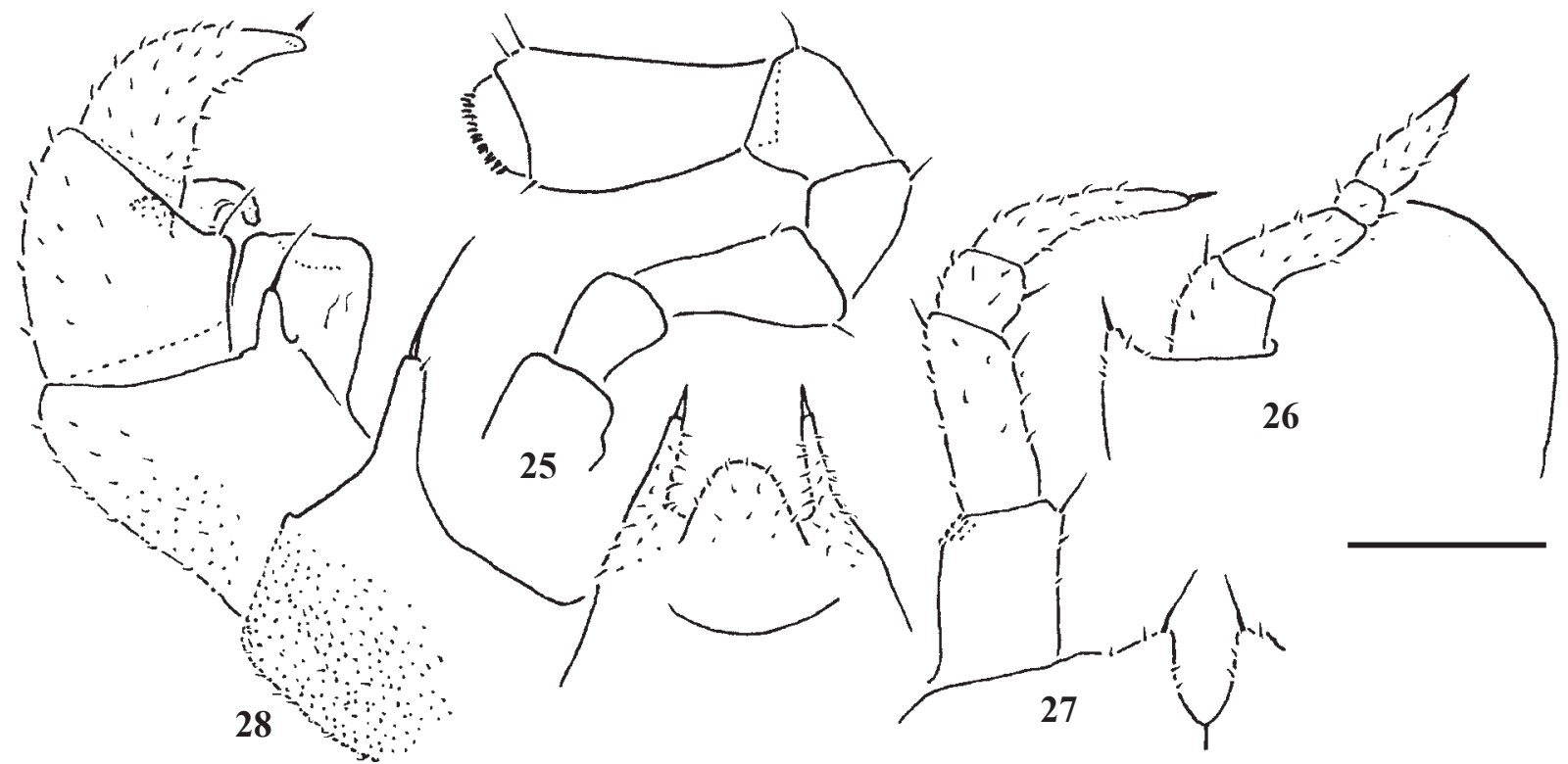

Figs 25-28. Rhopalomeris variegata Golovatch et Semenyuk, 2016, lighter $0^{7}$ from Kon Tum Province. 25 — antenna, lateral view; 26 leg 17, oral view; 27 - leg 18, oral view; 28 - telopod, oral view. Scale bar - 0.5 (26-28) or $0.25 \mathrm{~mm}$ (25).

Рис. 25-28. Rhopalomeris variegata Golovatch et Semenyuk, 2016, , более светлый О’ из провинции Кон-Тум. 25 - антенна, сбоку; 26 - нога 17, спереди; 27 - нога 18, спереди; 28 - телопод, спереди. Масштаб - 0,5 (26-28) или 0,25 мм (25). 


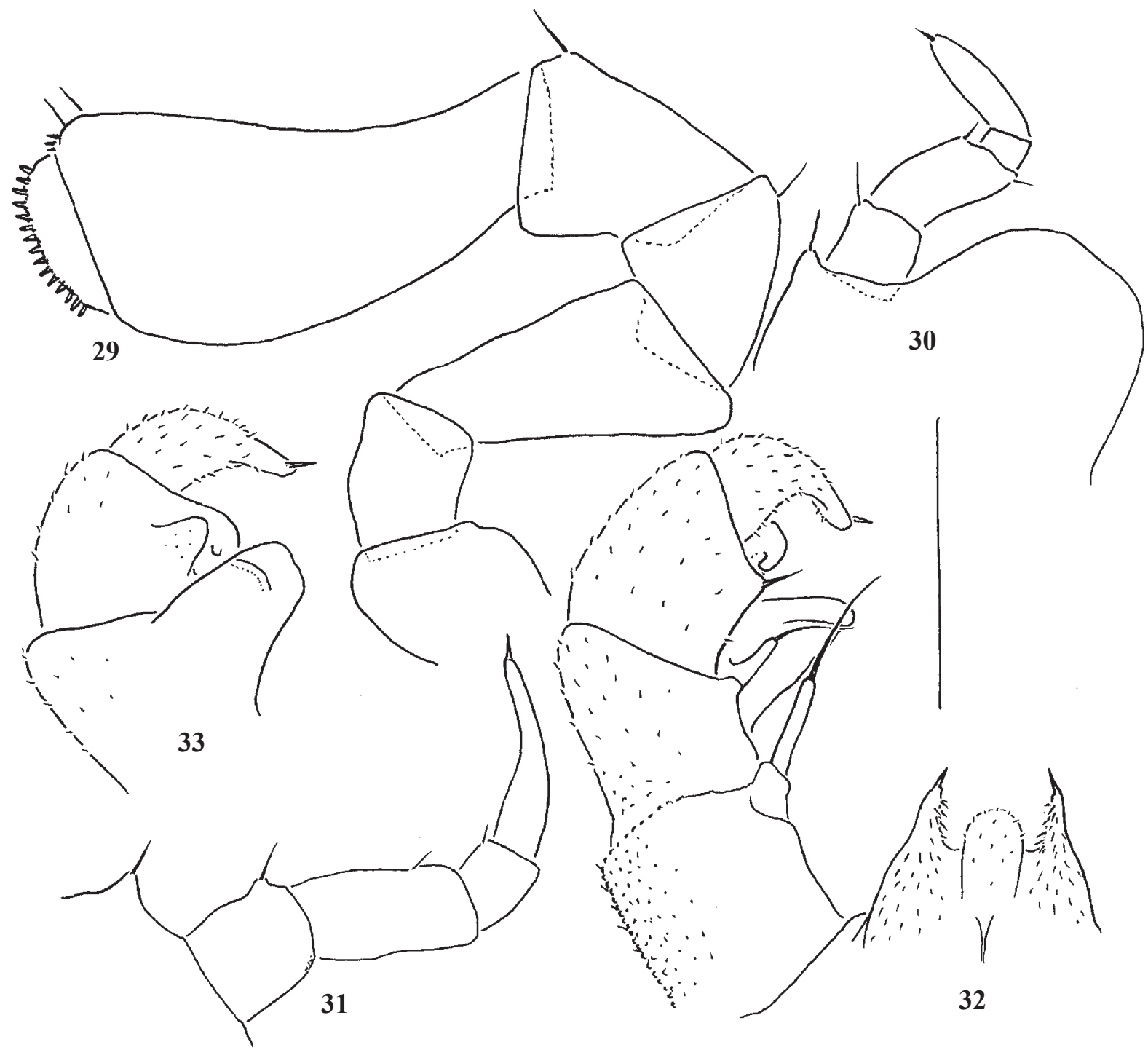

Figs 29-33. Rhopalomeris variegata Golovatch et Semenyuk, 2016, darker $0^{7}$ from Kon Tum Province. 29 — antenna, lateral view; 30 leg 17, oral view; 31 - leg 18, oral view; 32 - telopod, oral view; 33 - distal part of telopod, caudal view. Scale bar - $1.0 \mathrm{~mm}$.

Рис. 29-33. Rhopalomeris variegata Golovatch et Semenyuk, 2016, более тёмный О7 из провинции Кон-Тум. 29 — антенна, сбоку; 30 - нога 17, спереди; 31 - нога 18, спереди; 32 - телопод, спереди; 33 - дистальная часть телопода, сзади. Масштаб - 1,0 мм.

Antennomere 6 in several individuals $\left(O^{7}, 9\right)$ up to contrasting infuscate, dark brown (Figs 21-24). Tergum 2 with 7-11 fine, superficial, transverse striae, of which 4-6 crossing the dorsum, but mid-dorsal region usually with additional 3-5, incomplete, abbreviated, confused striolae behind last complete stria. $\sigma^{7}$ legs $17-19$ only slightly variable (Figs 25-33).

\section{References}

Golovatch S.I. 1983. On several new Glomeridae (Diplopoda) from Indochina // Annales Historico-Naturales Musei Nationalis Hungarici. Vol.75. P.107-116.

Golovatch S.I. 2015. A new species of the millipede genus Hyleoglomeris Verhoeff, 1910, from Tajikistan, Central Asia (Diplopo- da: Glomerida: Glomeridae) // Russian Entomological Journal. Vol.24. No.2. P.103-105.

Golovatch S.I., Semenyuk I.I. 2016. Two new species of the millipede family Glomeridae from Vietnam (Diplopoda: Glomerida) // Russian Entomological Journal. Vol.25. No.4. P.411-416.

Golovatch S.I., Geoffroy J.-J., Mauriès J.-P. 2006. Review of the millipede genus Hyleoglomeris Verhoeff, 1910 (Diplopoda, Glomerida, Glomeridae), with descriptions of new species from caves in Southeast Asia // Zoosystema. Vol.28. No.4. P.887-915.

Golovatch S.I., Geoffroy J.-J., VandenSpiegel D. 2013. On several new species of the millipede family Glomeridae from Vietnam (Diplopoda: Glomerida) // Arthropoda Selecta. Vol.22. No.3. P.201-206.

Silvestri F. 1917. Contributions to a knowledge of the Oriental Diplopoda Oniscomorpha. 1. The family Glomeridae // Records of the Indian Museum. Vol.13. P.103-151. 